\title{
Evaluation of efficacy of a biofilm-embedded bacteria-based vaccine against staphylococcal mastitis in sheep- A randomized, placebo-controlled field study
}

\author{
N. G. C. Vasileiou, ${ }^{1}$ D. C. Chatzopoulos,${ }^{1 *}$ P. J. Cripps,${ }^{2 *}$ K. S. loannidi, ${ }^{1 *}$ D. A. Gougoulis, ${ }^{1}$ T. M. Chouzouris, ${ }^{1}$ \\ D. T. Lianou, ${ }^{1}$ T. Calvo Gonzalez-Valerio, ${ }^{3}$ R. Guix Vallverdu, ${ }^{3}$ S. Argyros, ${ }^{3}$ M. Cesio, ${ }^{3}$ I. Font, ${ }^{3}$ \\ V. S. Mavrogianni, ${ }^{1}$ E. Petinaki, ${ }^{4}$ and G. C. Fthenakis ${ }^{1} \dagger$ \\ ${ }^{1}$ Veterinary Faculty, University of Thessaly, 43100 Karditsa, Greece \\ ${ }^{2}$ Institute of Veterinary Science, University of Liverpool, Neston, South Wirral, CH64 7TE, United Kingdom \\ ${ }^{3}$ Laboratorios Hipra S.A., 17170 Amer (Girona), Spain \\ ${ }^{4}$ University Hospital of Larissa, 41110 Larissa, Greece
}

\section{ABSTRACT}

Our objective was to evaluate the efficacy of a vaccine against staphylococcal mastitis in 5 dairy sheep farms, with 316 ewes in the vaccinated (V) group and 307 in the control $(\mathrm{C})$ group studied throughout a lactation period. Two administrations of the vaccine were performed during the last stage of gestation of ewes. Starting $15 \mathrm{~d}$ after lambing and at monthly intervals thereafter, up to 9 milk samplings were performed for bacteriological and cytological examinations. Staphylococcal isolates recovered were examined for biofilm formation. Blood samples were collected for measurement of IgG poly- $N$-acetylglucosamine-specific antibodies. The most frequently isolated bacteria were staphylococci: 56.4 and $76.1 \%$, respectively, of total isolates recovered from ewes of group $\mathrm{V}$ and $\mathrm{C}$, respectively; staphylococci as causal agents of mastitis were isolated less frequently from $\mathrm{V}(5.3 \%)$ than in ewes in C $(10.3 \%)$. Among mastitis-associated staphylococcal isolates recovered from $\mathrm{V}$ ewes, a smaller proportion was biofilm-forming than among ones from C: $53.2 \%$ versus $74.9 \%$ of isolates; biofilm-forming staphylococci as causal agents of mastitis were isolated less frequently from ewes in group $\mathrm{V}(2.3 \%)$ than in ewes in group C (6.0\%). Anti-poly- $N$-acetylglucosamine-specific antibody values increased in $\mathrm{V}$ ewes and were higher than in $\mathrm{C}$; a greater proportion of ewes with low antibody titers developed staphylococcal mastitis (41.4\%) than of $\mathrm{V}$ ewes with high antibody titers $(17.0 \%)$. Incidence risk of mastitis, staphylococcal mastitis, and biofilm-

Received January 12, 2019.

Accepted May 30, 2019

*These authors contributed equally and their names are listed alphabetically.

†Corresponding author: gcf@vet.uth.gr associated staphylococcal mastitis was smaller in $\mathrm{V}$ than in C: $36.7,17.1$, and $8.0 \%$ versus $44.3,30.9$, and $18.9 \%$, respectively. The first case of staphylococcal mastitis occurred later in $\mathrm{V}$ than in $\mathrm{C}$ : third versus second sampling point. Overall, efficacy of the vaccine was $44.6 \%$ for staphylococcal mastitis, $57.7 \%$ for biofilm-associated staphylococcal mastitis, $33.1 \%$ for staphylococcal intramammary infection, and $51.5 \%$ for biofilm-associated staphylococcal intramammary infection. Nevertheless, vaccination should not be the only means for controlling mastitis; other udder health management measures should be included therein to improve control of the infection.

Key words: biofilm formation, ewe, slime, subclinical mastitis, udder health, vaccine

\section{INTRODUCTION}

In ewes, bacterial mastitis is a financially significant problem, especially in dairy-type production systems (Gelasakis et al., 2015). It is also a predominant cause of decreased welfare in sheep farms (European Food Safety Authority, 2014). For mastitis control, a variety of approaches, including correct management in the milking parlor (Gelasakis et al., 2015; Vasileiou et al., 2018b) or administration of antibiotics at the end of a lactation period (Petridis and Fthenakis, 2014), can be applied; vaccination may also be implemented (Lacasta et al., 2015).

Staphylococcus aureus is a main causal agent of clinical mastitis, particularly in dairy production type flocks (Fthenakis and Jones, 1990; Gelasakis et al., 2015). Coagulase-negative staphylococci (mainly Staphylococcus epidermidis, Staphylococcus chromogenes, Staphylococcus simulans, and Staphylococcus xylosus) are the primary etiological agents of subclinical mastitis (Fthenakis et al., 1994; Onni et al., 2011; Gelasakis et al., 2015; Vasileiou et al., 2018b). 
Various factors have been implicated in the virulence of staphylococci and play a role in the pathogenesis of mastitis. Biofilm formation by staphylococci contributes to their survival and adherence on epithelial cells in the mammary gland, as well as to their dissemination within an affected mammary gland.

The objective of the study (University of Thessaly project reference no. 2566) was to evaluate efficacy of a vaccine against staphylococcal mastitis in ewes under field conditions and was performed in 5 dairy sheep farms. The staphylococcal antigen in the vaccine is based on a bacterin of $S$. aureus strain, expressing the exopolysaccharide poly- $N$-acetylglucosamine (PNAG), which is involved in biofilm formation by these bacteria (Perez et al., 2009; Prenafeta et al., 2010).

\section{MATERIALS AND METHODS}

\section{Number of Animals in the Study}

The study was designed to mix vaccinated $(\mathbf{V})$ and control (C) ewes in a 1:1 ratio within participating farms. As ewe was to be the unit of vaccination, sample size calculations were performed at the ewe level (Schukken et al., 2014). Previous data in Greece indicated that the incidence risk of new cases of mastitis of staphylococcal etiology in ewes was approximately $13.0 \%$ per lactation period (Fthenakis and Jones, 1990; Fthenakis, 1994). The size needed for each group was therefore 278 ewes, to reject the null hypothesis that incidence risk for vaccinated and control ewes was equal (i.e., efficacy of the vaccine was $0 \%$ ) with a probability of 0.80 . The type I error probability associated with this test of this null hypothesis was 0.05. Subsequently, because of the within-ewe dependency due to mixing (Halloran et al., 1997; Schukken et al., 2014), required sample size was increased by $20 \%$, thus resulting in 334 ewes in each group and total study size population of 668 ewes.

\section{Sheep Farms}

The trial started in January 2015, with data gathering in farms taking place until July 2016. Farm selection and inclusion in the study were based on convenience (i.e., the willingness of the farmers to collaborate and receive regular visits for examination and sampling of animals on their farm). All farms were located in the region of Thessaly in central Greece. In all farms, standard basic health management practices (anti-clostridial and antiBrucella melitensis vaccinations, administrations of anthelmintic products) were performed regularly. It is noted that no specific udder health management measures (e.g., teat-dipping, administration of antibiotics at end of lactation period) were employed in any farm in the study. Details of farms are shown in Table 1.

In farms $\mathrm{A}, \mathrm{P}$, and $\mathrm{S}$, all available ewes were enrolled in the study. In each of farms $\mathrm{K}$ and D, 160 ewes were selected for enrolment by using an electronic random number generator (www.randomresult.com) as they walked into the shed. In all farms, a centralized randomization schedule in a 1:1 ratio was performed (author GCF) for allocation of ewes in V or C groups. After allocation in a group, a standardized detailed clinical examination was performed (author NGCV) to assess the general health of the animals (Lovatt, 2010). Animals with clinically evident problems were excluded. Finally, 348 ewes remained in group V (326 adults and 22 ewe-lambs) and 344 in group C (318 adults and 26 ewe-lambs; Table 1). Ewes in each farm were identified using neck straps and plastic tags with unique farm-specific serial numbers. Farmers and farm personnel were not aware of the vaccination status of the animals.

In the 3 farms, in which machine-milking was applied, the scheduled periodic maintenance evaluations were performed by technical staff of the manufacturer at the set intervals. No manufacturing-related problems were detected in the milking system of any farm.

\section{Vaccination Schedule and Administration}

A vaccine licensed in European Union countries against clinical staphylococcal mastitis in ewes (Vimco, Hipra, Girona, Spain) was used (batches: 69VW-1, 75LQ-2, 75LQ-1, 77XW-1, 76CN-1, 79PJ-2, 77XW-1). Vaccination was carried out during the last stage of gestation of ewes, following the licensed schedule of the product. The initial administration was performed 110 d after introduction of rams into the flock of ewes (i.e., 6 to $5 \mathrm{wk}$ before the expected start of lambing season) and was followed by a repeat administration $21 \mathrm{~d}$ later. A timeline of the study is shown in Figure 1.

For transportation of vaccine from the laboratory to the sheep farms, vials were stored in portable refrigerators with ice packs. Transportation was performed by car.

Allocation concealment was performed. The investigator who administered the vaccine (NGCV), had not been aware in advance of the treatment for each new animal that she handled; group allocation of ewes was announced to her after she had finished the clinical examination of animal and had prepared it for vaccine or placebo administration.

Administration was performed after clipping the wool in the neck region of the animal. A dose of $2 \mathrm{~mL}$ of the product was injected intramuscularly. Control animals were injected intramuscularly with $2 \mathrm{~mL}$ of normal 
VASILEIOU ET AL.
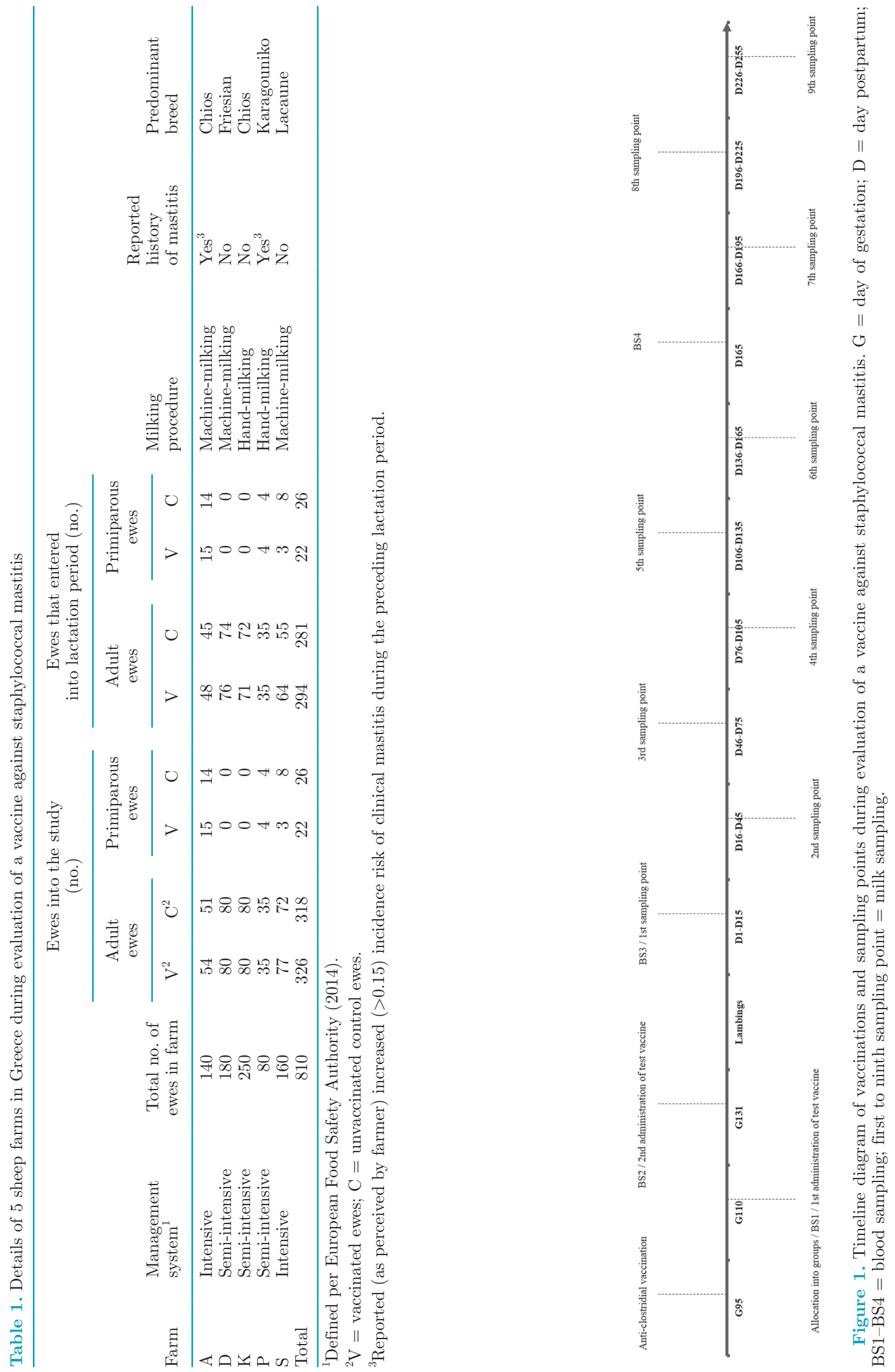

Journal of Dairy Science Vol. 102 No. 10, 2019 
saline. A plastic syringe and a hypodermic needle were used and discarded after a single administration. The first injection to each animal was performed at the left side of the neck; repeat injection was performed at the right side. All vaccine and placebo administrations were carried out by a principal investigator (NGCV).

The only other vaccine that had been administered to the ewes during the study period was an anti-clostridial vaccine, which had been given 2 wk before the initial administration of the vaccine under evaluation. The vaccine was injected subcutaneously in the area behind the front leg of the sheep.

\section{Examination of Animals and Samplings}

After vaccine administration, animals were observed by the farmer for any systemic or local reactions. If any were recorded, a detailed examination was performed (NGCV); subsequent examinations were performed every $3 \mathrm{~d}$ until the reaction had disappeared. In case of local reactions, the size, nature, and duration of presence were described after clinical examination (observation, palpation) of the region of vaccine injection.

After lambing, clinical examination of animals was routinely performed within the first $15 \mathrm{~d}$ and then at monthly intervals. In total, depending on the farm, up to 9 milk samplings were performed (Figure 1). On each sampling point, milk samples were collected from all ewes (both groups), which were in lactation period.

If cases of clinical mastitis were observed by the farmer, then the animal was examined (NGCV) within the next $24 \mathrm{~h}$.

A standardized clinical examination of the udder (observation, palpation, comparison between glands) was performed (NGCV; Fthenakis, 1994; Mavrogianni et al., 2005), and the first 2 squirts of secretion were drawn on the gloved hand of an assisting investigator and assessed. The investigators involved in sampling procedures wore disposable, nonsterile latex gloves (Alfa Gloves, Karabinis Medical SA, Peania, Greece). The person, who examined the animals and collected the milk samples, changed gloves after procedures in each animal were completed and before moving to the next one. If udder abnormalities were present, they were recorded.

The orifice, edge, and lower half of the body of the teat were disinfected by single-use sterile gauzes, onto which povidone iodine $7.5 \%$ solution (Betadine surgical scrub, Mundipharma Medical Company, Basel, Switzerland) had been poured, followed by wiping off by means of a new sterile gauze; different gauzes were used for each teat. Then, 10 to $15 \mathrm{~mL}$ of secretion was collected into a sterile container; separate samples were collected from each mammary gland into separate containers. Milk samples were then drawn directly onto a paddle for performing the California mastitis test (CMT).

Jugular blood samples were collected in tubes with no anticoagulant, on 4 occasions throughout the study, always from the same $\mathrm{V}$ and $\mathrm{C}$ randomly selected ewes ( $\mathrm{n}=10$ from each group) in each farm. Samples were collected immediately before initial and repeat vaccine administration (sampling points BS1 and BS2, respectively), as well as $3 \mathrm{wk}$ and 6 mo after repeat vaccination (sampling points BS3 and BS4, respectively) (Figure 1).

For transportation to the laboratory, all samples were stored in portable refrigerators with ice packs. Transportation was performed by car.

\section{Laboratory Examinations}

Microbiological Examinations. Laboratory procedures started within $5 \mathrm{~h}$ after collection. The investigators who processed the samples and recorded the results (authors NGCV and DCC) were not aware of their group of origin. Milk samples from each mammary gland were processed separately. Samples (10 $\mu \mathrm{L}$ ) were cultured using Columbia blood agar plates incubated aerobically at $37^{\circ} \mathrm{C}$ for $48 \mathrm{~h}$. If nothing had grown, media were re-incubated for another $24 \mathrm{~h}$. Bacterial identifications were performed by using standard, established techniques: morphological characteristics of colonies, Gram stain, and biochemical tests (Barrow and Feltham, 1993; Euzeby, 1997).

Cytological Examination. At ewe side, all milk samples were tested by use of the CMT. The test was performed as previously described for ewe milk (Schalm et al., 1971; Fthenakis, 1995) and scored always by the same person (NGCV). Five degrees of reaction (negative, trace, 1, 2, and 3) were described (Schalm et al., 1971). Smears were also produced from all milk samples and dried. These were stained by the Giemsa method for estimation of leukocyte subpopulations; proportion of leukocyte types therein was calculated by observing at least 10 fields of each milk film under magnification $10 \times$ and counting at $\geq 100$ leukocytes.

Subsequently, the microscopic cell counting method (Mccm; IDF reference method; International Dairy Federation, 1984) was performed in 1,006 milk samples.

Examination of Staphylococcal Isolates for In Vitro Biofilm Formation. All mastitis-associated staphylococcal isolates recovered from farms A, D, K, and $\mathrm{P}$ were tested for in vitro biofilm formation by a combination of culture appearance on Congo Red agar and microplate adhesion method. The methodology of the work and the techniques employed have been 
detailed by Vasileiou et al. (2018a). In brief, established techniques, previously described (Freeman et al., 1989; Vasudevan et al., 2003; Fabres-Klein et al., 2015), were followed. Finally, isolates have been classified as biofilm-forming or non-biofilm-forming by combining results of the 2 methods (Vasileiou et al., 2018a).

Detection of Anti-PNAG-Specific Antibodies in Blood Samples. Blood samples were centrifuged for serum collection in preparation for measurement of IgG PNAG-specific antibodies. Serum samples were diluted to 1:100. Diluted samples were assayed by an indirect ELISA in plates coated with purified PNAG (Prenafeta et al., 2010). This was confirmed with a specific monoclonal anti-deacetylated PNAG that had been kindly provided by Gerard Pier (Harvard Medical School, Harvard University, Boston, MA). In brief, 96-well plates were coated with the purified PNAG and blocked with a StabilCoat Immunoassay Stabilizer (SurModics, Eden Prairie, MN). Wells were incubated with the diluted samples; protein $\mathrm{G}$ conjugated with peroxidase (Pierce, Thermo Fisher Scientific, Waltham, MA) was used to detect bound total IgG antibodies (Prenafeta et al., 2010). The investigators who processed the samples (authors MC, IF) were not aware of their origin (farm, group).

Known positive and negative control serum samples were included on each assay plate. Finally, wells were incubated with a chromogenic substrate for the peroxidase; absorbance of the reaction was measured as optical density (OD) in a microplate reader at $405 \mathrm{~nm}$ (Sunrise equipped with Magellan 3.11 software; Tecan, Männedorf, Switzerland). Each sample was assayed twice by using the above methodology and controls.

\section{Data Management and Analysis}

All data were entered into Microsoft Excel (Microsoft Corp., Redmond, WA) and analyzed using IBM SPSS Statistics (ver. 21, IBM Corp., Armonk, NY).

Definitions. The following outcomes were studied: mastitis, staphylococcal mastitis, biofilm-associated staphylococcal mastitis, staphylococcal IMI, and biofilm-associated staphylococcal IMI. All outcomes referred to ewes (hence, animals with both glands affected were counted as one case).

Mastitis included clinical and subclinical mastitis. Clinical mastitis was defined in ewes with the presence of abnormal gross findings in a mammary gland (including changes in secretion; Fragkou et al., 2014); subclinical mastitis was defined in ewes in which a bacteriologically positive milk sample $[(\mathrm{a})>10$ colonies of the same organism and (b) no more than 2 different types of colonies] with concurrently increased CMT score $(\geq 1)$ plus neutrophil and lymphocyte proportion ( $\geq 65 \%$ of all leukocytes) was detected (Fragkou et al., 2014; Vasileiou et al., 2018b). Staphylococcal mastitis was defined in ewes, in which staphylococci were identified as causal agents of mastitis. Cases of staphylococcal mastitis caused by isolates forming biofilm were termed biofilm-associated staphylococcal mastitis (Vasileiou et al., 2018a,b). Recurrence of staphylococcal mastitis in a ewe was defined when a ewe with staphylococcal mastitis changed to not having staphylococcal mastitis and then again to having it.

Staphylococcal IMI was defined in ewes, in which a staphylococcal positive milk sample was detected, independent of cell content therein. Cases of staphylococcal IMI caused by isolates forming biofilm were termed biofilm-associated staphylococcal IMI.

Moreover, for the purposes of this report, the following definitions were used to compare the likelihood of occurrence of the various outcomes (disease or infection). Incidence rate was defined as the proportion of animals at risk that developed the condition when the time at risk was the same in each group. Incidence risk was defined as the proportion of animals at risk, which developed the condition when the time at risk differed between animals (for example, during an entire lactation which varied between individuals).

Quantitative information on the cellular content of ewe milk was obtained by using 2 sets of data: the CMT results and the results of the Mccm. Although it is generally established that CMT results are reliable proxy measurements for SCC (Fthenakis, 1995; Gonzalez-Rodríguez and Carmenes, 1996), we further confirmed that in the present study. Following assignment of numerical values to CMT scores (value 0 to score negative, value 1 to score trace, value 2 to score 1 , value 3 to score 2 , and value 4 to score 3 ) and $\log _{10^{-}}$ transformations, correlation between CMT scores and Mccm SCC was $\mathrm{r}=0.905$ (95\% CI: 0.893-0.915; $P<$ $0.001)$ and the corrected $\mathrm{R}^{2}$ was $81.4 \%$.

Analysis of Results Related to Bacterial Isolates. Evaluations of associations regarding vaccination status of ewes from which isolates had been recovered were performed by use of the Pearson chi-squared test or Fisher exact test as appropriate.

OD During Measurement of Anti-PNAGSpecific Antibodies in Serum Samples. Results of antibody measurements in serum samples were expressed as OD values. The mean OD value of the 2 duplicate examinations obtained during the PNAGspecific antibodies assay in the total IgG measurements was converted into a relative index percent (RIPC) using the following formula: 
$\mathrm{RIPC}=(\mathrm{OD}$ value sample $-\mathrm{OD}$ value negative control)/(OD value positive control - OD value negative control) $\times 100$.

A cut-off point of 6.0 RIPC for the anti-PNAG-specific total IgG in serum had been established in accordance with results obtained during validation of the assay (Prenafeta et al., 2010), as follows:

$$
\begin{aligned}
& \text { cut-off }=(\text { mean RIPC from negative serum samples } \\
& +2 \mathrm{SD})+[(\text { mean RIPC from negative serum samples } \\
& +2 \mathrm{SD}) \times(\text { variation coefficient of the technique })]
\end{aligned}
$$

Values above that cut-off point were considered positive, whereas values below that were considered negative.

Analysis of Results Related to Antibody Titers. Linear mixed models were used in analysis to account for repeated measures of anti-PNAG antibody titers over the course of the study. Time points of collecting data were selected as within-subjects variables and group allocation as between-subject factor. Independent variables (fixed effects) included study group (V or C), sampling point (BS1-BS4) and a sampling point by study group interaction.

Association of frequency of staphylococcal and biofilm-associated staphylococcal mastitis cases with positive or negative anti-PNAG antibody titers was evaluated by use of the Fisher exact test. Mean antiPNAG antibody titers between ewes that did or did not develop mastitis were compared by use of Student's $t$-test.

Modeling for Analysis of Mastitis Occurrence. For estimation of incidence rates, we took into account that a ewe might change from having to not having mastitis and vice versa; during the interval between sampling points, it was not possible to know what had happened between the 2 sampling points (i.e., how many cases of mastitis and cures might have occurred). Therefore, the following definitions were made (Mavrogianni et al., 2007).

- On a particular sampling point, a ewe was defined as being at risk of developing mastitis, if it had no mastitis on the previous sampling point.

- On the subsequent sampling point, this ewe could be either healthy (in which case it was still at risk to developing mastitis) or with mastitis (in which case it was not at risk).

- On subsequent sampling points, if this ewe was healthy, then it was again at risk.
- If a ewe was detected to be healthy on one sampling point but with mastitis on the next one, then mastitis was considered to have taken place halfway between the 2 sampling points; if a ewe was detected with mastitis on one sampling point but healthy on the next one, then mastitis was deemed to have been eliminated halfway between the 2 sampling points.

- If a ewe was detected with mastitis on 2 consecutive sampling points, then it was considered to have been with mastitis throughout the time between those 2 time points; conversely, if a ewe was found healthy on 2 consecutive sampling points, then it was considered to have been healthy throughout the time between those 2 time points.

Based on the above, it was possible to calculate incidence rates of mastitis at each sampling point. Further, it was possible to estimate the length of time for which a ewe was at risk before it developed mastitis, as well as the length of time that a ewe had mastitis.

Finally, the lactation period of ewes into the study was divided in 2 stages: the first included the first 4 sampling points and the second the subsequent sampling points, from fifth up to ninth.

Analysis of Results Related to Mastitis Occurrence. For calculations, all animals in group $\mathrm{V}$ or $\mathrm{C}$ (i.e., in all farms), as well as animals in group $\mathrm{V}$ or $\mathrm{C}$ in each of the 5 farms were taken into account. Then, calculations were made for clusters of farms, according to following variables: (a) intensive or semi-intensive management system, (b) hand- or machine-milking or (c) reported or not history of clinical mastitis. Comparisons were performed between groups $\mathrm{V}$ and $\mathrm{C}$ for (a) animals in the study (i.e., in all farms), (b) animals in individual farms, or (c) animals within a cluster of farms.

Comparison of the time when first case of mastitis outcomes occurred in $\mathrm{V}$ and $\mathrm{C}$ ewes was performed by the Mann-Whitney test for nonparametric data. Association of mastitis cases with stage of lactation (first or second) in ewes of group $\mathrm{V}$ or $\mathrm{C}$ was also evaluated by use of Pearson chi-squared test.

Vaccine Efficacy. Efficacy of the vaccine under evaluation was calculated as [(incidence rate on day i in group $\mathrm{C}$ - incidence rate on day i in group $\mathrm{V}$ ewes)/ incidence rate on day i in group $\mathrm{C}$ ewes] (Centers for Disease Control and Prevention, 2017). Efficacy was calculated for mastitis, staphylococcal mastitis, biofilmassociated staphylococcal mastitis, staphylococcal IMI, and biofilm-associated staphylococcal IMI on each of the 9 sampling points.

Significance. In all analyses, statistical significance was defined at $P<0.05$. 


\section{RESULTS}

\section{Postvaccination Adverse Reactions}

In total, adverse reactions were recorded in 2 group $\mathrm{V}$ ewes (incidence rate: $0.6 \%, 95 \%$ CI: $0.2-2.1 \%$ ). No reactions were recorded in group $\mathrm{C}$ animals (incidence rate: $0.0 \%, 95 \%$ CI: $0.0-1.1 \%$; $P=0.25$ between groups). The reactions referred to development of a hard nodule $3 \mathrm{~cm}$ in diameter, at the site of injection, 2 and $3 \mathrm{~d}$ after initial vaccination. The lesions progressively subsided within 3 wk.

\section{Monitoring of Ewes and Sample Collection During the Study}

Of the 692 ewes into the study, 623 entered into lactation period for sampling $(90.0 \%$, range among flocks: 81.3-100\%; Table 1); of these, 316 were in group V $(90.8 \%)$ and 307 in group $\mathrm{C}(89.2 \% ; P=0.25$ between groups). Reasons for which animals did not enter into the lactation period were sale, culling, death, abortion, or failure to lamb.

On average, animals were monitored for $154 \mathrm{~d}$ for $\mathrm{V}$ and $152 \mathrm{~d}$ for $\mathrm{C}$ group $(P=0.34)$. Adult ewes were monitored for a longer period than primiparous ewes: 154 and $134 \mathrm{~d}$, respectively $(P=0.003)$. In total, 3,637 milk samplings were performed: 1,853 in $\mathrm{V}$ and 1,784 in $\mathrm{C}$ ewes. A total of 362 blood samples were also collected: 180 from V and 182 from C ewes. Details are in Appendix Tables A1 and A2.

\section{Microbiological Findings}

Bacterial Isolation. In total, 428 bacterial isolates were recovered from ewes with mastitis. The most frequently isolated bacteria were Staphylococcus spp. (n $=290$ ), accounting for 56.4 and $76.1 \%$, respectively, of total isolates recovered from group $\mathrm{V}$ and $\mathrm{C}$, respectively $(P<0.001)$. Staphylococci as causal agents of mastitis were isolated less frequently from ewes in group V (from 99 of 1,853 samplings; $5.3 \%$ ) than in ewes in group C (from 184 of 1,784 samplings; $10.3 \%$; $P$ $<0.001$; Table 2, Appendix Tables A3 and A4). Other bacteria isolated included Corynebacterium spp., Streptococcus spp., Acinetobacter spp., Escherichia coli, and Mannheimia haemolytica.

No difference was observed in frequency of $S$. aureus isolates among staphylococcal isolates between the 2 groups: $4.1 \%$ versus $5.8 \%$ of isolates for group V and C, respectively $(P=0.33)$.

In Vitro Biofilm Formation. Of the 222 mastitisassociated isolates that were tested, $149(67.1 \%)$ were characterized as biofilm-forming. Among mastitis-asso-
Table 2. Frequency of bacterial isolates recovered from milk samples from ewes with mastitis in 5 farms throughout a lactation period, during evaluation of a vaccine against staphylococcal mastitis

\begin{tabular}{lcc}
\hline & \multicolumn{2}{c}{$\begin{array}{c}\text { No. of isolates, } \\
\text { (frequency of isolation, \%) }\end{array}$} \\
\cline { 2 - 3 } Microorganism & Group V & Group C $^{1}$ \\
\hline CNS & $97(53.6)$ & $175(70.9)$ \\
Staphylococcus aureus & $5(2.8)$ & $13(5.3)$ \\
Non-staphylococcal isolates & $79(43.6)$ & $59(23.9)$ \\
Total & 181 & 247 \\
\hline
\end{tabular}

${ }^{1} \mathrm{~V}=$ vaccinated ewes; $\mathrm{C}=$ unvaccinated control ewes.

${ }^{2}$ Main bacteria isolated: Corynebacterium spp., Streptococcus spp., Acinetobacter spp., Escherichia coli.

ciated staphylococcal isolates recovered from $\mathrm{V}$ group ewes, a smaller proportion was biofilm-forming than among those from $\mathrm{C}$ group ewes: $53.2 \%(42 / 79)$ versus $74.9 \%$ of isolates $(107 / 143$, respectively $(P<0.001$; Table 3, Appendix Table A5). Biofilm-forming staphylococci as causal agents of mastitis were isolated less frequently from ewes in group V (42 of 1,853 samplings; $2.3 \%$ ) than in ewes in group C (107 of 1,784 samplings; $6.0 \% ; P<0.001)$.

\section{Anti-Staphylococcal Biofilm Antibodies}

Anti-PNAG-specific antibody values increased in group $\mathrm{V}$ ewes $(P<0.001$ between sampling points for $\mathrm{V}$ group) and were higher than in $\mathrm{C}$ group ones ( $P<0.001$ between groups). Moreover, on sampling points BS3 and BS4, a greater proportion of group V ewes had increased antibody values (93.9 and 63.6\%, respectively) than of group $\mathrm{C}$ ewes (39.6 and $37.5 \%$, respectively; $P<0.001$ and $P=0.031$, respectively; Figure 2, Appendix Table A6).

There was an association of anti-PNAG antibody titers with risk of mastitis development: a greater proportion of ewes with RIPC $<6.0$ on sampling point BS3 (independent of group) subsequently developed staphy-

Table 3. Frequency (\%) of biofilm-forming staphylococcal isolates recovered from milk samples from ewes with mastitis in 5 farms throughout a lactation period, during evaluation of a vaccine against staphylococcal mastitis

\begin{tabular}{|c|c|c|}
\hline Farm & Group $\mathrm{V}^{1}$ & Group $\mathrm{C}^{1}$ \\
\hline $\mathrm{A}$ & $63.6(7 / 11)$ & $88.9(24 / 27)$ \\
\hline $\mathrm{D}$ & $83.3(10 / 12)$ & $68.6(24 / 35)$ \\
\hline $\mathrm{K}$ & $46.0^{\mathrm{a}}(23 / 50)$ & $76.5^{\mathrm{a}}(52 / 68)$ \\
\hline $\mathrm{P}$ & $33.3(2 / 6)$ & $53.8(7 / 13)$ \\
\hline Total & $53.2^{\mathrm{a}}(42 / 79)$ & $74.8^{\mathrm{a}}(107 / 143)$ \\
\hline
\end{tabular}

a Same superscript in the same row for comparison within the same farm: $P<0.01$.

${ }^{1} \mathrm{~V}=$ vaccinated ewes; $\mathrm{C}=$ unvaccinated control ewes. 


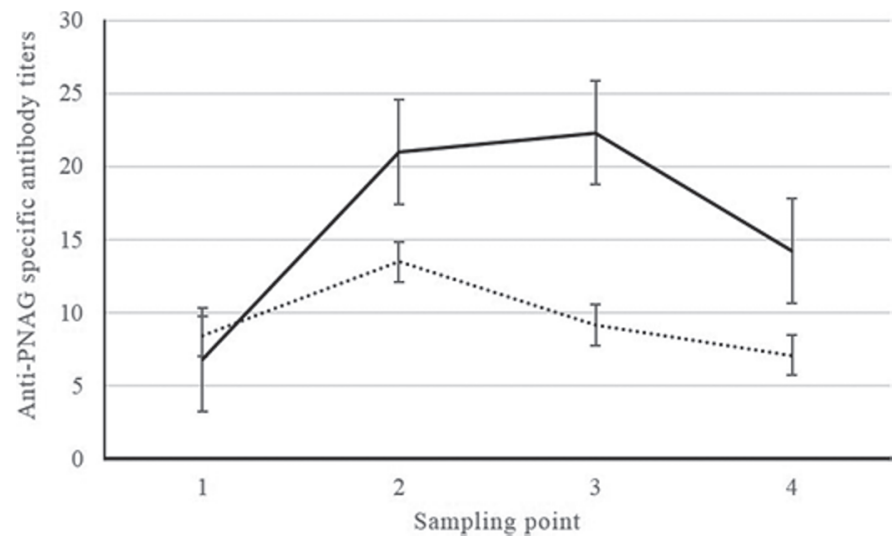

Figure 2. Mean values of anti-PNAG-specific antibody titers in blood samples from ewes in 5 farms throughout a lactation period, during evaluation of a vaccine against staphylococcal mastitis. PNAG: poly- $N$-acetylglucosamine. Continuous line: $\mathrm{V}$ group (vaccinated ewes), dotted line: C group (unvaccinated control ewes). Sampling point: 1 = before initial vaccination; 2 = before booster vaccination; 3 $=3$ wk after booster vaccination; $4=6$ mo after booster vaccination. Error bars indicate SEM.

lococcal or biofilm-associated staphylococcal mastitis (12/29 and 9/20, 41.4 and $45.0 \%)$ than of group $V$ ewes with RIPC $>6.0$ on the same occasion $(8 / 47$ and $2 / 38$, 17.0 and $5.3 \%$, respectively; $P=0.020$ and $P<0.001$, respectively). Further, a greater proportion of ewes with RIPC $<6.0$ on sampling point BS3 subsequently developed biofilm-associated IMI $(9 / 20,45.0 \%)$ than of group V ewes with RIPC $>6.0$ on the same occasion $(4 / 38,10.5 \% ; P=0.004)$; however, no such association with staphylococcal IMI was found (13/29 versus $14 / 47 ; P=0.14)$.

\section{Occurrence of Mastitis}

When all animals in the study were taken into account, the incidence risk of mastitis, staphylococcal mastitis, and biofilm-associated staphylococcal mastitis was smaller in group $\mathrm{V}$ than in group $\mathrm{C}$ ewes: $36.7 \%$ (95\% CI: $31.6 \%-42.2 \%$ ), $17.1 \%$ (95\% CI: $13.3 \%-21.6 \%$ ), and $8.0 \%(95 \%$ CI: $5.3 \%-12.1 \%)$ versus $44.3 \%(95 \%$ CI: $38.9 \%-49.9 \%$ ), $30.9 \%$ (95\% CI: $26.0 \%-36.3 \%$ ), and $18.9 \%$ (95\% CI: $14.4 \%-24.3 \%)$, respectively $(P=0.027$, $<0.001$, and $<0.001$, respectively). In all farms, the incidence risk of staphylococcal mastitis and biofilmassociated staphylococcal mastitis was smaller in group $\mathrm{V}$ than in group $\mathrm{C}$ ewes (Appendix Tables A7, A8, and A9). Further, it emerged that incidence risk of staphylococcal mastitis and biofilm-associated staphylococcal mastitis also was always smaller in group $\mathrm{V}$ than in group $\mathrm{C}$ ewes in all clusters evaluated (Table 4).

In adult ewes, the incidence risk of mastitis, staphylococcal mastitis, and biofilm-associated staphylococcal mastitis was smaller in group $\mathrm{V}$ than in group $\mathrm{C}$ ewes: $37.1,17.3$, and $6.5 \%$ versus $47.3,31.3$, and $16.4 \%$, respectively $(P<0.007)$. In contrast, in primiparous ewes, no such differences were seen in the various mas-

Table 4. Frequency [no. of cases ${ }^{1}$ and incidence risk ${ }^{2}(\%)$ ] of outcomes in clusters of sheep farms throughout a lactation period, during evaluation of a vaccine against staphylococcal mastitis

\begin{tabular}{|c|c|c|c|}
\hline $\begin{array}{l}\text { Farm } \\
\text { (ewes in lactation period) }\end{array}$ & Mastitis & $\begin{array}{l}\text { Staphylococcal } \\
\text { mastitis }\end{array}$ & $\begin{array}{l}\text { Biofilm-associated } \\
\text { staphylococcal mastitis }\end{array}$ \\
\hline \multicolumn{4}{|c|}{ Intensive management system (flocks $\mathrm{A}$ and $\mathrm{S}$ ) } \\
\hline $\mathrm{V}(\mathrm{n}=130)$ & $44(33.8)$ & $23(17.7)^{\mathrm{b}}$ & $6(9.5)^{\mathrm{a}}$ \\
\hline \multicolumn{4}{|c|}{ Semi-intensive management system (flocks D, K, and P) } \\
\hline $\mathrm{V}(\mathrm{n}=186)$ & $72(38.7)^{\mathrm{a}}$ & $31(16.7)^{\mathrm{c}}$ & $14(7.5)^{\mathrm{c}}$ \\
\hline $\mathrm{C}(\mathrm{n}=185)$ & $90(48.6)^{\mathrm{a}}$ & $59(31.9)^{\mathrm{c}}$ & $34(18.4)^{\mathrm{c}}$ \\
\hline \multicolumn{4}{|c|}{ Hand-milking (flocks $\mathrm{K}$ and $\mathrm{P}$ ) } \\
\hline \multicolumn{4}{|c|}{ Machine-milking (flocks A, D, and S) } \\
\hline $\mathrm{V}(\mathrm{n}=206)$ & $59(28.6)$ & $29(14.1)^{\mathrm{c}}$ & $9(6.5)^{\mathrm{c}}$ \\
\hline $\mathrm{C}(\mathrm{n}=196)$ & $69(35.2)$ & $52(26.5)^{\mathrm{c}}$ & $21(15.8)^{\mathrm{c}}$ \\
\hline \multicolumn{4}{|c|}{ Reported history of clinical mastitis ${ }^{3}$ (flocks A and P) } \\
\hline $\mathrm{V}(\mathrm{n}=102)$ & $28(27.5)$ & $14(13.7)^{\mathrm{a}}$ & $8(6.9)^{\mathrm{c}}$ \\
\hline \multicolumn{4}{|c|}{ No reported history of clinical mastitis ${ }^{3}$ (flocks D, K. and S) } \\
\hline
\end{tabular}

\footnotetext{
${ }^{\mathrm{a}-\mathrm{c}}$ Same superscript in the same column for comparison within the same cluster: ${ }^{\mathrm{a}} 0.026<P<0.05,{ }^{\mathrm{b}} 0.01<P<0.025,{ }^{\mathrm{c}} P<0.01$.

${ }^{1}$ Number of ewes with respective outcome during the lactation period (animals were taken into account only once, irrespective of new cases that they might have developed).

${ }^{2}$ Number of ewes with respective outcome during the lactation period/number of ewes that entered in lactation period.

${ }^{3}$ Reported (as perceived by farmer) increased (>0.15) incidence risk of clinical mastitis during the preceding lactation period.
} 
titis outcomes between the 2 groups: 31.8, 13.6, and $4.5 \%$ versus $11.5,11.5$, and $0.0 \%$, respectively $(P>$ $0.085)$.

Only 8 cases of clinical staphylococcal mastitis were recorded throughout the study, of which 1 was recorded in a group $\mathrm{V}$ ewe and 7 were recorded in group $\mathrm{C}$ ewes $(P=0.004)$. Of these cases, 5 were caused by biofilmforming staphylococci, none in group $\mathrm{V}$ ewes $(P=$ 0.003 when compared with cases in group C).

Incidence rates of mastitis and staphylococcal mastitis were smaller in group $\mathrm{V}$ than in group $\mathrm{C}$ up to the fourth and sixth sampling points, respectively. The incidence rate of biofilm-associated staphylococcal mastitis was smaller in group $\mathrm{V}$ throughout the study (Figure 3, Appendix Table A9). Incidence rates during the first stage of lactation differed between $\mathrm{V}$ and $\mathrm{C}$ ewes for all outcomes: $31.9,18.4$, and $5.4 \%$ versus $52.5,37.5$, and $16.1 \%$ for mastitis, staphylococcal mastitis, and biofilm-associated staphylococcal mastitis, respectively $(P<0.001)$; in contrast, no differences were recorded between the 2 groups during the second stage of lactation: $34.3,18.7$, and $6.0 \%$ versus $38.8,22.7$, and $7.3 \%$, respectively $(P>0.22)$.

The first case of staphylococcal and biofilm-associated staphylococcal mastitis occurred later in $\mathrm{V}$ (median value: third sampling point) than in $\mathrm{C}$ (median value: second sampling point) ewes $(P<0.003)$. Also, a smaller proportion of the cases of staphylococcal mastitis in $\mathrm{V}$ ewes occurred during the first stage of the lactation period than those in $\mathrm{C}$ ewes: $59.3 \%(32 / 54)$ versus $85.3 \%(81 / 95)$ of ewes, respectively $(P<0.001)$.

The median duration of staphylococcal and biofilmassociated staphylococcal mastitis was $30 \mathrm{~d}$ for both

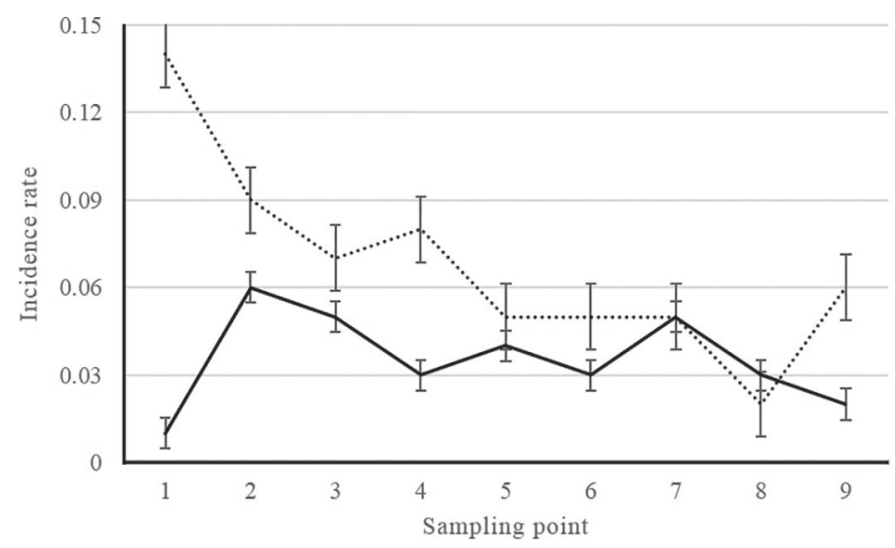

Figure 3. Incidence rates (proportion of animals at risk, which developed the condition when the time at risk was the same in each group) of staphylococcal mastitis in ewes in 5 farms throughout a lactation period, during evaluation of a vaccine against mastitis Continuous line: vaccinated ewes (V group), dotted line: unvaccinated control ewes (C group). Sampling point: first within the first $15 \mathrm{~d}$ after lambing; subsequent ones at monthly intervals thereafter. Error bars indicate SEM of rate. groups $(P>0.40)$. Further, staphylococcal mastitis recurrence was observed in 7 of the $54 \mathrm{~V}$ ewes $(13.0 \%)$ and in 21 of the $95 \mathrm{C}$ ewes $(22.1 \% ; P=0.12)$.

Incidence risks of staphylococcal IMI and biofilmassociated staphylococcal IMI were smaller in group V than in group C ewes: $25.3 \%$ (95\% CI: $20.8-30.4 \%$ ) and 8.2\% (95\% CI: $5.7-11.8 \%$ ) versus $37.8 \%$ (95\% CI: $32.6-$ $43.3 \%$ ) and $16.9 \%$ (95\% CI: $13.0-21.7 \%$ ), respectively $(P<0.001$ and $=0.001$, respectively $)$. Incidence risk of staphylococcal IMI and biofilm-associated staphylococcal IMI was 26.2 and $8.5 \%$ versus 38.8 and $18.2 \%$, respectively $(P \leq 0.001)$, for adult ewes and 13.6 and $4.5 \%$ versus 26.9 and $3.8 \%$, respectively $(P>0.22)$ for primiparous ewes. The first case of staphylococcal IMI occurred later in V (median value: third sampling point) than in in $\mathrm{C}$ (median value: second sampling point) ewes $(P<0.001)$. Duration of IMI was the same for ewes in both groups: $30 \mathrm{~d}$. Finally, IMI recurrence was observed in 17 of the $80 \mathrm{~V}$ ewes $(21.3 \%)$ and in 29 of the $116 \mathrm{C}$ ewes $(25.0 \%, P=0.54$; Appendix Tables $\mathrm{A} 10$ and A11).

\section{Efficacy of the Vaccine}

Overall, efficacy of the vaccine was $17.2 \%$ for mastitis, $44.6 \%$ for staphylococcal mastitis, and $57.7 \%$ for biofilm-associated staphylococcal mastitis. Moreover, efficacy of the vaccine against staphylococcal IMI was $33.1 \%$ and against biofilm-associated staphylococcal IMI was $51.5 \%$ overall. Efficacy was greater during the first stage of the lactation period $(39.2,50.9$, and $66.5 \%$, for mastitis, staphylococcal mastitis, and biofilm-associated staphylococcal mastitis, respectively) than in the second stage (always $<18 \%$ for all outcomes; $P<0.001$ for comparisons between the 2 stages). On the various sampling points, the efficacy of the vaccine was up to $65 \%$ for mastitis, up to $91 \%$ for staphylococcal mastitis, and up to $100 \%$ for biofilm-associated staphylococcal mastitis (Appendix Table A12).

\section{DISCUSSION}

\section{Efficacy of the Test Vaccine Against Mastitis}

The present results have indicated that the vaccine reduced occurrence of staphylococcal mastitis, clinical and subclinical, in ewes (Appendix Table A7). The study was carried out in 5 dairy sheep farms and included a large number of animals; further, the study extended throughout an entire lactation period. The results were uniform across the 5 farms, with incidence risk of mastitis in vaccinated ewes being smaller than in controls. The results have corroborated previously re- 
ported experimental findings in which the vaccine had been found effective after intramammary challenge of CNS (Vasileiou et al., 2016). During this study we were careful to use precise, robust, and reproducible definitions of outcome. Nevertheless, it is almost inevitable that our assays had sensitivities and specificities that were $<100 \%$. The expected effect of errors in assays would be to underestimate the true size and statistical significance of effects but not alter their direction; this in turn means that the differences that were observed between experimental groups may actually be underestimates of the vaccine's true effect.

In the present study, most mastitis cases were subclinical mastitis (approximately $95 \%$ of all cases). Very few cases of clinical mastitis were recorded during the study, most of them in unvaccinated animals. Moreover, significantly fewer CNS have been identified as causal agents of mastitis from vaccinated ewes, thus indicating an immunization against these bacteria. If identification of coagulase-negative isolates to species level had been performed, some of the various outcomes might have differed; for example, duration of mastitis might have been shorter in vaccinated ewes and frequency of recrudescence smaller, whereas more new IMI might have been recognized. Nevertheless, from the viewpoint of IMI with biofilm-forming isolates, there would be small differences, as Vasileiou et al. (2018a) defined the condition independent of the species involved, but based on slime production and biofilm formation by the isolates.

The vaccine has been found to be effective in adult animals, whereas in primiparous ewes no significant differences were seen between vaccinated and control animals (Table A7). During the study, primiparous ewes had a shorter lactation period than older ones. The smaller risk of infection coupled with effective mammary defense mechanisms (Kraft et al., 1987; Fragkou et al., 2007) could have accounted for the smaller incidence risk of mastitis in young animals.

In vaccine efficacy studies, in which mixed populations (vaccinated and control individuals) are in contact, there is a bias toward no effect (Halloran et al., 1997). Hence, one may postulate that, possibly, in commercial situations, in farms with only vaccinated ewes, the effects of the vaccine would be more pronounced.

Vaccination has been found to lead to a reduced incidence risk of mastitis in all clusters of farms that were investigated (Table 4). The management system applied in flocks has been found to be the most significant predictor for subclinical mastitis, with highest risk in flocks under semi-intensive or intensive management (Vasileiou et al., 2018b). Farms under semi-intensive or intensive management were included in the present study and a higher incidence risk was seen in flocks under semi-intensive management. Reduction of mastitis occurrence after vaccination was seen independent of the management system applied in farms. Management system can include various aspects of flock husbandry and organization (e.g., housing facilities and nutrition), which have been considered to affect development of mastitis in ewes (Gelasakis et al., 2015, Fthenakis et al., 2017). Further, hand-milking has been identified as a significant predictor for staphylococcal mastitis (Vasileiou et al., 2018a). This was confirmed in the present study: in the cluster of farms applying handmilking (vaccinated and control ewes), the incidence risk was higher than in the cluster with farms applying machine-milking. Milkers, from whose hands staphylococci have been frequently isolated (Salgado-Ruiz et al., 2015), may not always clean them properly or wear gloves as part of the milking routine, hence contributing to transmission of these bacteria to ewes (Marco Melero, 1994). Independent of the milking procedure applied in flocks, the vaccine was found to confer immunity against mastitis. In relation to the reported history of mastitis, the finding of higher mastitis incidence risk in the cluster with flocks with no reported history underlines that it is difficult for farmers to estimate the true frequency of mastitis; moreover, farmers would only notice clinical manifestations of mastitis, thus missing cases of subclinical mastitis.

In relation to breed, the highest incidence risk of mastitis was recorded in a flock with Chios breed ewes. This breed is considered to be particularly susceptible to infections, with prevalence of subclinical mastitis found to be approximately $32 \%$ (Vasileiou et al., 2018c), which was 6 percentage points above the recently found national average of $26 \%$ (Vasileiou et al., 2018b). Although the vaccine offered immunity in ewes in that flock, the highest incidence risk among vaccinated ewes was recorded in the animals of that farm.

The vaccine is licensed against staphylococcal mastitis, but specifically targets cases caused by staphylococcal isolates forming biofilm. Biofilm formation is related to increased adhesion properties by bacteria and can lead in colonization of the bacteria onto mammary epithelial cells and subsequent damage to the parenchyma, which can account for increased pathogenicity of the respective isolates for the mammary gland of ewes (Vasileiou et al., 2018a). The findings of the present study have indicated that efficacy of the vaccine was greater against these organisms than against mastitis caused by staphylococcal species generally (biofilm- or non-biofilm-forming isolates) and, of course, mastitis caused by any etiological agent (Appendix Table A4). This was expected, as the vaccine's antigenic compo- 
nent would act specifically against biofilm formation by staphylococci; thus, biofilm-forming isolates would be cleared more effectively.

Nevertheless, cases of mastitis occurred even in vaccinated ewes. Mastitis is a multifactorial problem and none of the many approaches used for its control is fully effective. Various factors, unrelated to the vaccine, may be responsible, for example, inappropriate cleaning of the milking system by the farm staff after the end of the milking routine can lead in multiplication of staphylococci in milking clusters, which increases risk for infection of ewes in the subsequent milking; further, management factors (e.g., nutrition) can influence the immune status of ewes and their response to vaccination (Caroprese et al., 2015; Lacasta et al., 2015). It is noteworthy that in a study performed in cows, in which a vaccine against mastitis with the same staphylococcal component as this vaccine, had been evaluated, only a moderate reduction in incidence rate of staphylococcal mastitis was found (Schukken et al., 2014). In a recent paper, we have indicated areas with increased risk of biofilm-associated staphylococcal mastitis, based on ecological niche modeling for predicting space distribution of mastitis (Giannakopoulos et al., 2019). Administration of the vaccine in ewes located in such areas might be considered as a targeted means for reducing incidence risk of mastitis.

\section{Duration of Efficacy of the Test Vaccine Against Mastitis}

The effects of vaccination were prominent during the first $4 \mathrm{mo}$ of the lactation period (Figure 3). Efficient control of mastitis during that stage is particularly beneficial, as risk of infection is increased due to postpartum immunosuppression (Barbagianni et al., 2015; Caroprese et al., 2015). Milk yield of ewes is highest at that stage (Ruiz et al., 2000; Oravcova et al., 2006); therefore, control of mastitis benefits ewes in dairy (increased milk production) and meat (optimum growth rate of lambs) production systems.

\section{Anti-PNAG Antibody Titers}

Antibody titers in immunized animals were significantly higher than in unvaccinated controls (Table A6), although in the latter ewes' titers might have increased as the result of naturally occurring infections.

Perez et al. (2009) have pointed out that anti-PNAG antibodies could be used only to confirm induction of immunity after administration of the vaccine, while their use for detection of natural mammary infections might not be straightforward. This seems reasonable, given the nature of the infection and that staphylococci can cause a variety of infections in ewes, some of them totally unrelated to the udder, for example, osteomyelitis or vaginal infections (Kaarsemaker et al., 1997; de Paula Vasconcelos et al., 2016). Increase of antibody titers in vaccinated ewes confirmed development of immune response by these animals, which, in turn, might have contributed in the more effective clearance of biofilm-producing isolates. Increased antibody titers were recorded for up to $180 \mathrm{~d}$ post-booster vaccination, hence, in theory, 155 to $160 \mathrm{~d}$ into the lactation period. Possibly, staphylococcal infections occurring in vaccinated ewes may also be responsible, at least to some extent, for the increased titers rather than these being a long-standing effect of vaccination.

\section{Implications for Mastitis Control in Sheep Flocks}

It is noted that in none of the farms were specific udder health management measures used by shepherds. This allowed testing of the possible benefits of administration of the vaccine in reducing staphylococcal mammary infections in flocks. The results make clear that vaccination alone could not eliminate staphylococcal mastitis. Hence, vaccine administration would need to be considered within the frame of a complete udder health management and to be combined with other management procedures (e.g., correct milking routine, appropriate milking system maintenance, culling of ewes with long-standing infections, administration of antimicrobials at the end of a lactation period), to eliminate relevant mammary infections. All of these can work synergistically to improve control of mastitis.

\section{CONCLUSIONS}

The findings indicated that the vaccine under evaluation can lead to reduced incidence risk of staphylococcal mastitis. The effect was more pronounced in adult ewes and during the first 4 mo of lactation period; it was independent of management system, milking procedure, reported history of mastitis, or animal breed. Anti-PNAG antibodies were detected in vaccinated ewes after administration of the vaccine. Nevertheless, the results of the study indicate that for control of mastitis in ewes, vaccination should not be considered as the only means for reducing mastitis within an udder health program; other udder health management measures (e.g., correct milking routine, appropriate milking system maintenance, culling of ewes with long-standing infections, administration of antimicrobials at the end of a lactation period) should be included and can work synergistically to improve control of mastitis. 


\section{ACKNOWLEDGMENTS}

Partial funding for the work described in this work has been provided by Laboratorios Hipra S.A., Amer (Girona), Spain. The company did not have any influence in the design of the study, in collection, analysis, and interpretation of data (except results of immunological examination, which were performed at their laboratory) and in writing the manuscript.

\section{REFERENCES}

Barbagianni, M. S., V. S. Mavrogianni, A. I. Katsafadou, S. A. Spanos, V. Tsioli, A. D. Galatos, M. Nakou, I. Valasi, P. G. Gouletsou, and G. C. Fthenakis. 2015. Pregnancy toxaemia as predisposing factor for development of mastitis in sheep during the immediately postpartum period. Small Rumin. Res. 130:246-251.

Barrow, G. I., and R. K. A. Feltham. 1993. Manual for the Identification of Medical Bacteria. 3rd ed. Cambridge University Press, Cambridge, United Kingdom.

Caroprese, M., I. Giannenas, and G. C. Fthenakis. 2015. Interactions between nutritional approaches and defences against microbial diseases in small ruminants. Vet. Microbiol. 181:8-14.

Centers for Disease Control and Prevention (CDC). 2017. Principles of Epidemiology in Public Health Practice. 3rd ed. An Introduction to Applied Epidemiology and Biostatistics. US Department of Health and Human Services, Atlanta, GA.

de Paula Vasconcelos, C. O., F. Z. Brandao, G. Martins, B. Penna, J. M. Goncalves de Souza-Fabjan, and W. Lilenbaum. 2016. Qualitative and quantitative analysis of bacteria from vaginitis associated with intravaginal implants in ewes following estrus synchronization. Ciência Rural 46:632-636.

European Food Safety Authority. 2014. Scientific opinion on the welfare risks related to the farming of sheep for wool, meat and milk production. EFSA J. 12:3933-4060.

Euzeby, J. P. 1997. List of bacterial names with standing in nomenclature: A folder available on the Internet. Int. J. Syst. Bacteriol. 47:590-592.

Fabres-Klein, M. H., M. J. C. Santos, R. C. Klein, G. N. de Souza, and A. D. B. Ribon. 2015. An association between milk and slime increases biofilm production by bovine Staphylococcus aureus. BMC Vet. Res. 11:3.

Fragkou, I. A., C. M. Boscos, and G. C. Fthenakis. 2014. Diagnosis of clinical or subclinical mastitis in ewes. Small Rumin. Res. 118:86-92.

Fragkou, I. A., V. S. Mavrogianni, P. J. Cripps, D. A. Gougoulis, and G. C. Fthenakis. 2007. The bacterial flora in the teat duct of ewes can protect against and can cause mastitis. Vet. Res. 38:525-545.

Freeman, D. J., F. R. Falkiner, and C. T. Keane. 1989. New method of detecting slime production by coagulase negative staphylococci. J. Clin. Pathol. 42:872-874.

Fthenakis, G. C. 1994. Prevalence and aetiology of subclinical mastitis in ewes of southern Greece. Small Rumin. Res. 13:293-300.

Fthenakis, G. C. 1995. California Mastitis Test and Whiteside Test in diagnosis of subclinical mastitis of dairy ewes. Small Rumin. Res. 16:271-276.

Fthenakis, G. C., M. S. Barbagianni, I. A. Fragkou, D. A. Gougoulis, A. I. Katsafadou, V. S. Mavrogianni, I. G. Petridis, and N. G. C. Vasileiou. 2017. Elucidation of predisposing factors for ovine mastitis contributes to sustainable control of the disease. Page 60 in Proc. 9th International Sheep Veterinary Congress, Harrogate, UK. Sheep Veterinary Society, Penicuik, UK.

Fthenakis, G. C., and J. E. T. Jones. 1990. Incidence and aetiology of clinical ovine mastitis in flocks in Central Macedonia, Greece. Bull. Hell. Vet. Med. Soc. 41:133-141.

Fthenakis, G. C., R. R. Marples, J. F. Richardson, and J. E. T. Jones. 1994. Some properties of coagulase-negative staphylococci isolated from cases of ovine mastitis. Epidemiol. Infect. 112:171-176.
Gelasakis, A. I., V. S. Mavrogianni, I. G. Petridis, N. G. C. Vasileiou, and G. C. Fthenakis. 2015. Mastitis in sheep - The last 10 years and the future of research. Vet. Microbiol. 181:136-146.

Giannakopoulos, A., N. G. C. Vasileiou, D. A. Gougoulis, P. J. Cripps, K. S. Ioannidi, D. C. Chatzopoulos, C. Billinis, V. S. Mavrogianni, E. Petinaki, and G. C. Fthenakis. 2019. Use of geographical information system and ecological niche modelling for predicting potential space distribution of subclinical mastitis in ewes. Vet. Microbiol. 228:119-128.

Gonzalez-Rodríguez, M. C., and P. Carmenes. 1996. Evaluation of the California mastitis test as a discriminant method to detect subclinical mastitis in ewes. Small Rumin. Res. 21:245-250.

Halloran, M. E., C. J. Struchiner, and I. M. Longini Jr.. 1997. Study designs for evaluating different efficacy and effectiveness aspects of vaccines. Am. J. Epidemiol. 146:789-803.

International Dairy Federation. 1984. Recommended methods for somatic cell counting in milk. Bul. Int. Dairy Fed. 168.

Kaarsemaker, S., G. H. I. M. Walenkamp, and A. E. J. van der Bogaard. 1997. New model for chronic osteomyelitis with Staphylococcus aureus in sheep. Clin. Orthop. Relat. Res. 339:246-252.

Kraft, R., M. Bachmann, K. Bachmann, H. Buerki, M. W. Hess, H. Cottier, and R. D. Stoner. 1987. Satisfactory primary tetanus antitoxin responses but markedly reduced germinal center formation in 1st draining lymph nodes of aging mice. Clin. Exp. Immunol. $67: 447-453$.

Lacasta, D., L. M. Ferrer, J. J. Ramos, J. M. Gonzalez, A. Ortin, and G. C. Fthenakis. 2015. Vaccination schedules in small ruminant farms. Vet. Microbiol. 181:34-46.

Lovatt, F. 2010. Clinical examination of sheep. Small Rumin. Res. 92:72-77.

Marco Melero, J. C. 1994. Mastitis in Laxta Breed Sheep: Epidemiology, Diagnosis and Control. Doctoral thesis, University of Zaragoza, Zaragoza, Spain.

Mavrogianni, V. S., P. J. Cripps, and G. C. Fthenakis. 2007. Bacterial flora and risk of infection of the ovine teat duct and mammary gland throughout lactation. Prev. Vet. Med. 79:163-173.

Mavrogianni, V. S., G. C. Fthenakis, H. Brooks, N. Papaioannou, P. J. Cripps, I. Taitzoglou, G. Brellou, and P. Saratsis. 2005. The effects of inoculation of Mannheimia haemolytica into the teat of lactating ewes. Vet. Res. 36:13-25.

Onni, T., G. Sanna, J. Larsen, and S. Tola. 2011. Antimicrobial susceptibilities and population structure of Staphylococcus epidermidis associated with ovine mastitis. Vet. Microbiol. 148:45-50.

Oravcova, M., M. Margetin, D. Peskovicova, J. Dano, M. Milerski, L. Hetenyi, and P. Polak. 2006. Factors affecting milk yield and ewe's lactation curves estimated with test-day models. Czech J. Anim. Sci. 51:483-490.

Perez, M. M., A. Prenafeta, J. Valle, J. Penades, C. Rota, C. Solano, J. Marco, M. J. Grillo, I. Lasa, J. M. Irache, T. Maira-Litran, J. Jimenez-Barbero, L. Costa, G. B. Pier, D. de Andres, and B. Amorena. 2009. Protection from Staphylococcus aureus mastitis associated with poly-N-acetyl beta-1,6 glucosamine specific antibody production using biofilm-embedded bacteria. Vaccine 27:2379-2386.

Petridis, I. G., and G. C. Fthenakis. 2014. Administration of antibiotics to ewes at the beginning of the dry-period. J. Dairy Res. $81: 9-15$.

Prenafeta, A., R. March, A. Foix, I. Casals, and L. Costa. 2010. Study of the humoral immunological response after vaccination with a Staphylococcus aureus biofilm-embedded bacterin in dairy cows: Possible role of the exopolysaccharide specific antibody production in the protection from Staphylococcus aureus induced mastitis. Vet. Immunol. Immunopathol. 134:208-217.

Ruiz, R., L. M. Oregui, and M. Herrero. 2000. Comparison of models for describing the lactation curve of Latxa sheep and an analysis of factors affecting milk yield. J. Dairy Sci. 83:2709-2719.

Salgado-Ruiz, T. B., A. Rodriguez, D. Gutierrez, B. Martinez, P. Garcia, A. Espinoza-Ortega, A. R. Martinez-Campos, S. LagunasBernabe, F. Vicente, and C. M. Arriaga-Jordan. 2015. Molecular characterization and antimicrobial susceptibility of Staphylococcus 
aureus from small-scale dairy systems in the highlands of Central Mexico. Dairy Sci. Technol. 95:181-196.

Schalm, O. W., E. J. Carroll, and N. C. Jain. 1971. Bovine Mastitis, Lea and Febiger, Philadelphia, PA.

Schukken, Y. H., V. Bronzo, C. Locatelli, C. Pollera, N. Rota, A. Casula, F. Testa, L. Scaccabarozzi, R. March, D. Zalduendo, R. Guix, and P. Moroni. 2014. Efficacy of vaccination on Staphylococcus aureus and coagulase-negative staphylococci intramammary infection dynamics in 2 dairy herds. J. Dairy Sci. 97:5250-5264.

Vasileiou, N. G. C., D. C. Chatzopoulos, D. A. Gougoulis, S. Sarrou, A. I. Katsafadou, V. Spyrou, V. S. Mavrogianni, E. Petinaki, and G. C. Fthenakis. 2018a. Slime-producing staphylococci as causal agents of subclinical mastitis in sheep. Vet. Microbiol. 224:93-99.

Vasileiou, N. G. C., P. J. Cripps, K. S. Ioannidi, D. C. Chatzopoulos, D. A. Gougoulis, S. Sarrou, D. C. Orfanou, A. P. Politis, T. Calvo Gonzalez-Valerio, S. Argyros, V. S. Mavrogianni, E. Petinaki, and G. C. Fthenakis. 2018b. Extensive countrywide field investigation of subclinical mastitis in sheep in Greece. J. Dairy Sci. 101:72977310.

Vasileiou, N. G. C., D. A. Gougoulis, V. Riggio, K. S. Ioannidi, D. C. Chatzopoulos, V. S. Mavrogianni, E. Petinaki, and G. C. Fthenakis. 2018c. Association of subclinical mastitis prevalence with sheep breeds in Greece. J. Dairy Res. 85:317-320.

Vasileiou, N. G. C., V. S. Mavrogianni, K. S. Ioannidi, D. C. Chatzopoulos, T. Calvo Gonzalez Valerio, R. Guix Vallverdu, S. Argyros, and G. C. Fthenakis. 2016. Efficacy of a novel vaccine against biofilm formation by staphylococci, in protecting ewes against experimentally induced staphylococcal mastitis. Page 593 in Proc. 29th World Buiatrics Congress, Dublin, Ireland. Cattle Association of Veterinary Ireland, Dublin, Ireland.

Vasudevan, P., M. K. M. Nair, T. Annamalai, and K. S. Venkitanarayanan. 2003. Phenotypic and genotypic characterization of bovine mastitis isolates of Staphylococcus aureus for biofilm formation. Vet. Microbiol. 92:179-185.

\section{APPENDIX}

Table A1. Details of monitoring of ewes in 5 farms throughout a lactation period, during evaluation of a vaccine against staphylococcal mastitis

\begin{tabular}{|c|c|c|c|c|c|c|c|c|}
\hline \multirow[b]{2}{*}{ Farm } & \multicolumn{2}{|c|}{$\begin{array}{l}\text { Ewes that entered } \\
\text { into lactation period (no.) }\end{array}$} & \multicolumn{2}{|c|}{$\begin{array}{l}\text { Mean days in the } \\
\text { lactation period }\end{array}$} & \multicolumn{2}{|c|}{$\begin{array}{l}\text { Milk samplings } \\
\text { performed in ewes }\end{array}$} & \multicolumn{2}{|c|}{$\begin{array}{l}\text { Blood samples } \\
\text { collected from ewes }\end{array}$} \\
\hline & Group $V^{2}$ & Group $C^{2}$ & Group V & Group C & Group V & Group C & Group V & Group C \\
\hline D & $76 / 0$ & $74 / 0$ & $182 /-$ & $179 /-$ & $516 /-$ & $495 /-$ & 37 & 38 \\
\hline $\mathrm{K}$ & $71 / 0$ & $72 / 0$ & $164 /-$ & $162 /-$ & $436 /-$ & $446 /-$ & 40 & 38 \\
\hline $\mathrm{P}$ & $35 / 4$ & $35 / 4$ & $68 / 68$ & $68 / 68$ & $105 / 12$ & $105 / 12$ & 29 & 30 \\
\hline
\end{tabular}

${ }^{1}$ No. of ewes sampled on each sampling point presented in Appendix Table A2.

${ }^{2} \mathrm{~V}=$ vaccinated ewes; $\mathrm{C}=$ unvaccinated control ewes.

${ }^{3} \mathrm{~m} / \mathrm{n}=$ adult ewes/primiparous ewes.

Table A2. Number of ewes sampled in 5 farms throughout a lactation period, during evaluation of a vaccine against staphylococcal mastitis

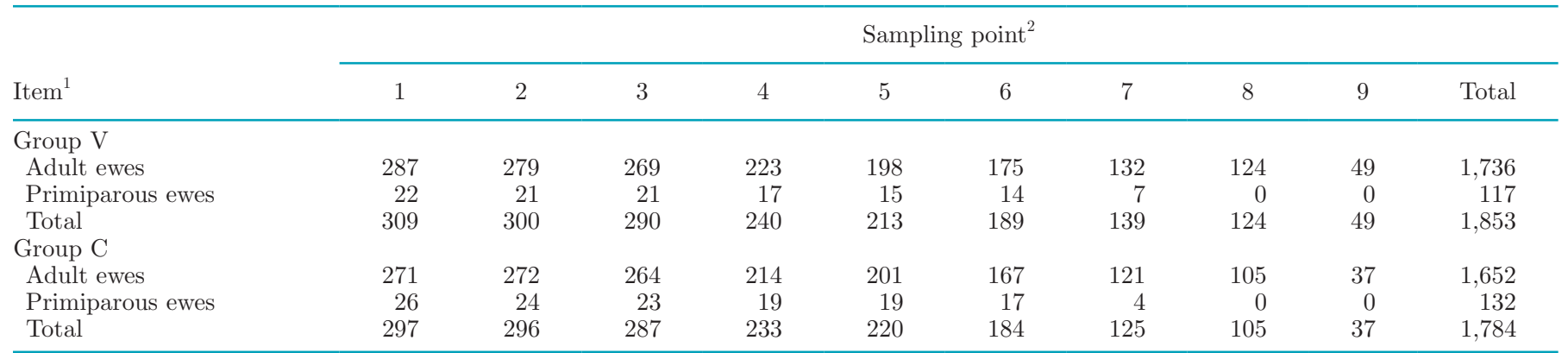

${ }^{1} \mathrm{~V}=$ vaccinated ewes; $\mathrm{C}=$ unvaccinated control ewes.

${ }^{2}$ The first sampling point occurred within the first $15 \mathrm{~d}$ after lambing; subsequent sampling points occurred at monthly intervals thereafter.

Table A3. Frequency of staphylococcal isolates recovered from milk samples from ewes in 5 farms throughout a lactation period, during evaluation of a vaccine against staphylococcal mastitis

No. of isolates (frequency of isolation, \%) from IMI

\begin{tabular}{lcc}
\cline { 2 - 3 } Microorganism & Group V & Group C \\
\hline CNS & $139(95.9)$ & $229(94.2)$ \\
Staphylococcus aureus & $6(4.1)$ & $14(5.8)$ \\
\hline
\end{tabular}

${ }^{1} \mathrm{~V}=$ vaccinated ewes; $\mathrm{C}=$ unvaccinated control ewes. 
Table A4. Details of bacterial isolation from milk samples from ewes with mastitis in 5 farms throughout a lactation period, during evaluation of a vaccine against staphylococcal mastitis

\begin{tabular}{|c|c|c|c|c|c|c|}
\hline \multirow[b]{2}{*}{ Farm } & \multicolumn{3}{|c|}{ Group $V^{1}$} & \multicolumn{3}{|c|}{ Group $\mathrm{C}^{1}$} \\
\hline & $\mathrm{Sa}^{2}$ & CNS & Other $^{2}$ & $\mathrm{Sa}^{2}$ & CNS & Other $^{2}$ \\
\hline A & 0 & 11 & 26 & 2 & 25 & 7 \\
\hline D & 0 & 12 & 10 & 1 & 34 & 11 \\
\hline K & 3 & 47 & 24 & 0 & 68 & 31 \\
\hline $\mathrm{P}$ & 0 & 6 & 4 & 2 & 11 & 2 \\
\hline S & 2 & 21 & 15 & 8 & 37 & 8 \\
\hline Total & 5 & 97 & 79 & 13 & 175 & 59 \\
\hline
\end{tabular}

${ }^{1} \mathrm{~V}=$ vaccinated ewes; $\mathrm{C}=$ unvaccinated control ewes.

${ }^{2} \mathrm{Sa}=S$. aureus; other $=$ non-staphylococci.

Table A5. Details of isolation of biofilm-forming staphylococcal isolates from milk samples from ewes with mastitis in 5 farms throughout a lactation period, during evaluation of a vaccine against staphylococcal mastitis

\begin{tabular}{lccccc}
\hline & \multicolumn{2}{c}{ Group V$^{1}$} & & \multicolumn{2}{c}{ Group C $^{1}$} \\
\cline { 2 - 3 } \cline { 5 - 6 } Farm & $\mathrm{Sa}^{2}$ & $\mathrm{CNS}$ & & $\mathrm{Sa}^{2}$ & $\mathrm{CNS}$ \\
\hline $\mathrm{A}$ & 0 & 7 & & 2 & 22 \\
$\mathrm{D}$ & 0 & 10 & & 1 & 23 \\
$\mathrm{~K}$ & 3 & 20 & & 0 & 52 \\
$\mathrm{P}$ & 0 & 2 & & 1 & 6 \\
Total & 3 & 39 & & 4 & 103 \\
\hline
\end{tabular}

${ }^{1} \mathrm{~V}=$ vaccinated ewes; $\mathrm{C}=$ unvaccinated control ewes.

${ }^{2} \mathrm{Sa}=$ S. aureus.

Table A6. Mean values of anti-PNAG ${ }^{1}$-specific antibody values in blood samples from ewes in 5 farms throughout a lactation period, during evaluation of a vaccine against staphylococcal mastitis

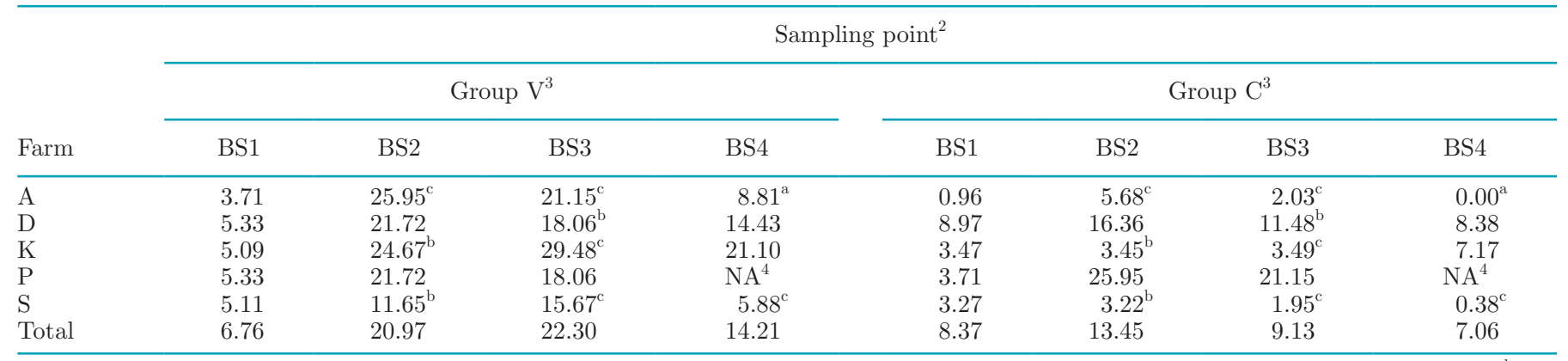

${ }^{\mathrm{a}}{ }^{\mathrm{c}}$ Same superscript in the same row for comparison between groups within the same farm at the same sampling point: ${ }^{\mathrm{a}} 0.026<P<0.05,{ }^{\mathrm{b}} 0.01$ $<P<0.025,{ }^{\mathrm{c}} P<0.01$.

${ }^{1} \mathrm{PNAG}=$ poly- $N$-acetylglucosamine.

${ }^{2} \mathrm{BS} 1=$ before initial vaccination; $\mathrm{BS} 2=$ before booster vaccination; BS3 $=3 \mathrm{wk}$ after booster vaccination; BS4 $=6$ mo after booster vaccination.

${ }^{3} \mathrm{~V}=$ vaccinated ewes; $\mathrm{C}=$ unvaccinated control ewes.

${ }^{4} \mathrm{NA}=$ not applicable. 
Table A7. Mastitis occurrence in ewes in 5 farms throughout a lactation period, during evaluation of a vaccine against staphylococcal mastitis

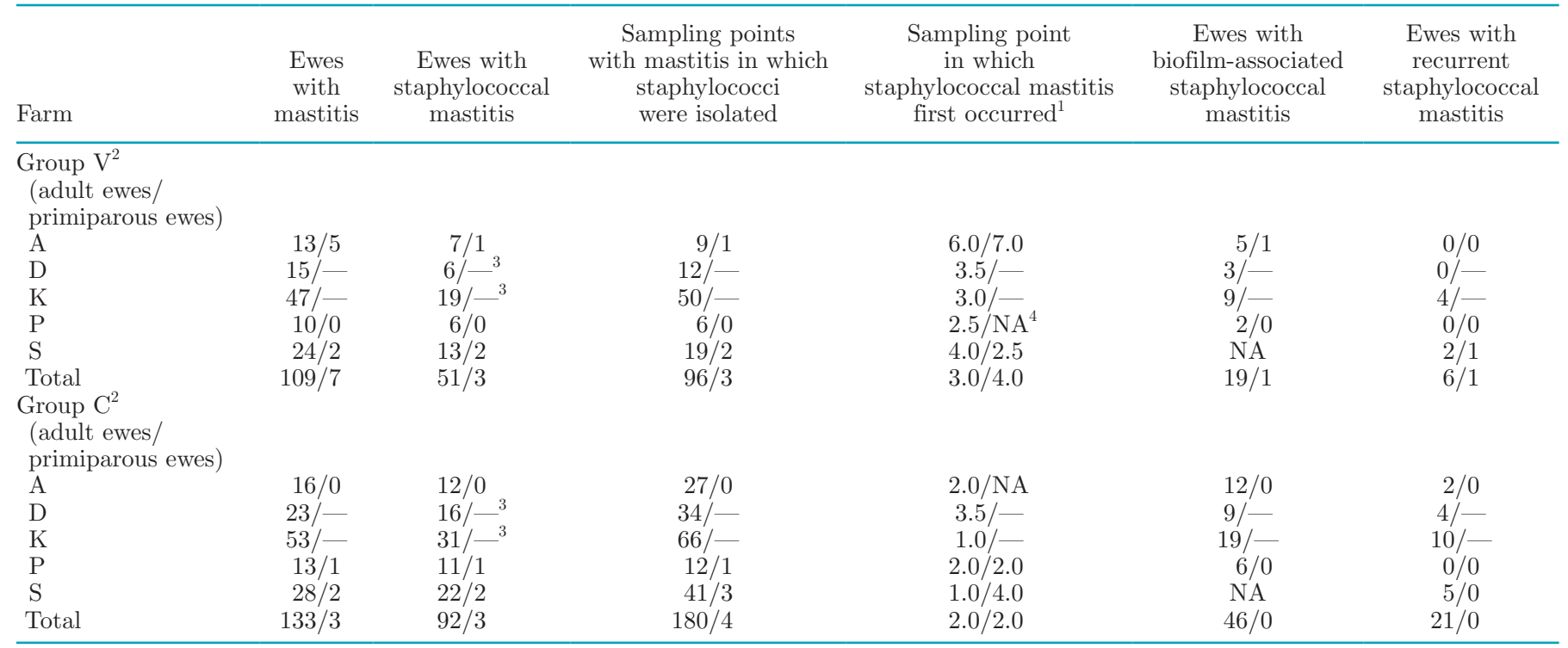

${ }^{1}$ Median value.

${ }^{2} \mathrm{~V}=$ vaccinated ewes; $\mathrm{C}=$ unvaccinated control ewes.

${ }^{3}-=$ no primiparous ewes enrolled in the study in this farm.

${ }^{4} \mathrm{NA}=$ not applicable.

Table A8. Frequency [no. of cases ${ }^{1}$ and incidence risk ${ }^{2}(\%)$ ] of outcomes in ewes in 5 farms throughout a lactation period, during evaluation of a vaccine against staphylococcal mastitis

\begin{tabular}{lccc}
\hline $\begin{array}{l}\text { Farm (no. of ewes } \\
\text { in lactation period) }\end{array}$ & Mastitis & $\begin{array}{c}\text { Staphylococcal } \\
\text { mastitis }\end{array}$ & $\begin{array}{c}\text { Biofilm-associated } \\
\text { staphylococcal mastitis }\end{array}$ \\
\hline Group V & $18(28.6)$ & $8(12.7)$ & $6(9.5)^{\mathrm{a}}$ \\
$\mathrm{A}(\mathrm{n}=63)$ & $15(19.7)$ & $6(7.9)^{\mathrm{c}}$ & $3(3.9)$ \\
$\mathrm{D}(\mathrm{n}=76)$ & $47(66.2)$ & $19(26.8)^{\mathrm{b}}$ & $9(12.7)^{\mathrm{b}}$ \\
$\mathrm{K}(\mathrm{n}=71)$ & $10(25.6)^{\mathrm{a}}$ & $6(15.4)^{\mathrm{b}}$ & $2(5.1)^{\mathrm{a}}$ \\
$\mathrm{P}(\mathrm{n}=39)$ & $26(38.8)$ & $15(22.4)^{\mathrm{b}}$ & $\mathrm{NA}^{4}$ \\
$\mathrm{~S}(\mathrm{n}=67)$ & $116(36.7)^{\mathrm{a}}$ & $54(17.1)^{\mathrm{c}}$ & $20(8.0)^{\mathrm{c}}$ \\
Total & $16(27.1)$ & $12(20.3)$ & $12(20.3)^{\mathrm{a}}$ \\
Group C & $23(31.1)$ & $16(21.6)^{\mathrm{c}}$ & $9(12.2)^{\mathrm{b}}$ \\
A $(\mathrm{n}=59)$ & $53(73.6)$ & $31(43.1)^{\mathrm{b}}$ & $19(26.4)^{\mathrm{b}}$ \\
$\mathrm{D}(\mathrm{n}=74)$ & $14(35.9)^{\mathrm{a}}$ & $12(30.8)^{\mathrm{b}}$ & $6(15.4)^{\mathrm{a}}$ \\
$\mathrm{K}(\mathrm{n}=72)$ & $30(47.6)$ & $24(38.1)^{\mathrm{b}}$ & $\mathrm{NA}^{\mathrm{b}}$ \\
$\mathrm{P}(\mathrm{n}=39)$ & $136(44.3)^{\mathrm{a}}$ & $95(30.9)^{\mathrm{c}}$ & $46(18.9)^{\mathrm{c}}$ \\
$\mathrm{S}(\mathrm{n}=63)$ & & & \\
Total & & & \\
\hline
\end{tabular}

${ }^{\mathrm{a}-\mathrm{c}}$ Same superscript in the same column for comparison within the same farm: ${ }^{\mathrm{a}} 0.026<P<0.05,{ }^{\mathrm{b}} 0.01<P$ $<0.025,{ }^{\mathrm{c}} P<0.01$.

${ }^{1}$ Number of ewes with respective outcome during the lactation period (animals were taken into account only once, irrespective of new cases that they might had developed).

${ }^{2}$ The proportion of animals at risk, which developed the condition when the time at risk differed between animals (for example, during an entire lactation which varied between individuals).

${ }^{3} \mathrm{~V}=$ vaccinated ewes; $\mathrm{C}=$ unvaccinated control ewes.

${ }^{4} \mathrm{NA}=$ not applicable. 
Table A9. Details of incidence rates ${ }^{1}$ of mastitis in ewes in 5 farms throughout a lactation period, during evaluation of a vaccine against staphylococcal mastitis

\begin{tabular}{|c|c|c|c|c|c|c|c|c|c|}
\hline \multirow[b]{2}{*}{ Outcome (\%) } & \multicolumn{9}{|c|}{ Sampling point ${ }^{2}$} \\
\hline & 1 & 2 & 3 & 4 & 5 & 6 & 7 & 8 & 9 \\
\hline \multicolumn{10}{|l|}{ Group $V^{3}$} \\
\hline Mastitis & 5.5 & 6.8 & 6.8 & 6.6 & 7.4 & 5.1 & 8.6 & 7.6 & 4.3 \\
\hline Staphylococcal mastitis & 1.3 & 5.7 & 4.7 & 3.1 & 3.9 & 3.4 & 5.5 & 2.5 & 2.2 \\
\hline Biofilm-associated staphylococcal mastitis & 0.0 & 2.0 & 1.8 & 0.4 & 0.5 & 0.6 & 3.1 & 0.8 & 2.2 \\
\hline Staphylococcal mammary carriage & 2.9 & 0.7 & 0.7 & 1.3 & 4.9 & 2.3 & 3.1 & 0.8 & 0.0 \\
\hline Staphylococcal mastitis & 13.9 & 8.4 & 6.8 & 7.6 & 5.0 & 4.7 & 5.3 & 2.0 & 5.7 \\
\hline Biofilm-associated staphylococcal mastitis & 6.4 & 3.3 & 2.3 & 3.8 & 1.5 & 0.6 & 3.5 & 1.0 & 2.9 \\
\hline Staphylococcal mammary carriage & 1.7 & 1.8 & 2.7 & 1.4 & 5.0 & 5.3 & 1.8 & 2.0 & 2.9 \\
\hline
\end{tabular}

${ }^{1}$ The proportion of animals at risk, which developed the condition when the time at risk was the same in each group.

${ }^{2}$ First sampling point within the first $15 \mathrm{~d}$ after lambing; subsequent ones at monthly intervals thereafter.

${ }^{3} \mathrm{~V}=$ vaccinated ewes; $\mathrm{C}=$ unvaccinated control ewes.

Table A10. Occurrence of staphylococcal and biofilm-associated staphylococcal IMI in ewes in 5 farms throughout a lactation period, during evaluation of a vaccine against staphylococcal mastitis

\begin{tabular}{|c|c|c|c|c|c|}
\hline Farm & $\begin{array}{c}\text { Ewes with } \\
\text { staphylococcal IMI }\end{array}$ & $\begin{array}{l}\text { Sampling points with } \\
\text { IMI from which } \\
\text { staphylococci } \\
\text { were isolated }\end{array}$ & $\begin{array}{c}\text { Sampling } \\
\text { point in } \\
\text { which IMI first }_{\text {occurred }^{1}}\end{array}$ & $\begin{array}{c}\text { Ewes with } \\
\text { biofilm-associated } \\
\text { staphylococcal IMI }\end{array}$ & $\begin{array}{l}\text { Ewes with } \\
\text { recurrent IMI }\end{array}$ \\
\hline A & $8 / 1$ & $9 / 1$ & $6.0 / 7.0$ & $5 / 1$ & $0 / 0$ \\
\hline $\mathrm{S}$ & $20 / 2$ & $37 / 3$ & $4.5 / 2.5$ & NA & $3 / 1$ \\
\hline Total & $77 / 3$ & $187 / 4$ & $3.0 / 4.0$ & $25 / 1$ & $16 / 1$ \\
\hline \multicolumn{6}{|c|}{$\begin{array}{l}\text { Group C } C^{2} \\
\text { (adult ewes/ } \\
\text { primiparous ewes) }\end{array}$} \\
\hline A & $18 / 2$ & $35 / 2$ & $2.0 / 4.0$ & $16 / 1$ & $4 / 0$ \\
\hline
\end{tabular}

${ }^{1}$ Median value.

${ }^{2} \mathrm{~V}=$ vaccinated ewes; $\mathrm{C}=$ unvaccinated control ewes.

${ }^{3}-=$ no primiparous ewes enrolled in the study in this farm.

${ }^{4} \mathrm{NA}=$ not applicable. 
Table A11. Details of incidence rates ${ }^{1}$ of staphylococcal and biofilm-associated staphylococcal IMI in ewes in 5 farms throughout a lactation period, during evaluation of a vaccine against staphylococcal mastitis

\begin{tabular}{|c|c|c|c|c|c|c|c|c|c|}
\hline \multirow[b]{2}{*}{ Outcome (\%) } & \multicolumn{9}{|c|}{ Sampling point ${ }^{2}$} \\
\hline & 1 & 2 & 3 & 4 & 5 & 6 & 7 & 8 & 9 \\
\hline Staphylococcal IMI & 4.2 & 6.1 & 6.8 & 4.8 & 8.9 & 6.3 & 7.8 & 2.5 & 2.2 \\
\hline Biofilm-associated staphylococcal IMI & 1.6 & 2.7 & 1.8 & 0.4 & 1.5 & 1.1 & 3.1 & 1.7 & 2.2 \\
\hline \multicolumn{10}{|l|}{ Group $C^{3}$} \\
\hline Staphylococcal IMI & 16.2 & 10.2 & 7.2 & 8.1 & 5.4 & 8.9 & 6.1 & 4.1 & 8.6 \\
\hline
\end{tabular}

${ }^{1}$ The proportion of animals at risk, which developed the condition when the time at risk was the same in each group.

${ }^{2}$ First sampling point within the first $15 \mathrm{~d}$ after lambing; subsequent ones at monthly intervals thereafter.

${ }^{3} \mathrm{~V}=$ vaccinated ewes; $\mathrm{C}=$ unvaccinated control ewes.

Table A12. Efficacy of a vaccine against staphylococcal mastitis in ewes in 5 farms throughout a lactation period

\begin{tabular}{lrrrrrrrrr}
\hline & \multicolumn{9}{c}{ Sampling point $^{1}$} \\
\cline { 2 - 9 } Outcome (\%) & \multicolumn{1}{c}{1} & \multicolumn{1}{c}{2} & \multicolumn{1}{c}{3} & \multicolumn{1}{c}{4} & 5 & 6 & 7 & 8 & 9 \\
\hline Mastitis & 64.6 & 38.3 & 25.1 & 19.1 & 0.0 & 33.1 & 0.0 & 66.0 & 74.6 \\
Staphylococcal mastitis & 90.7 & 31.6 & 31.7 & 59.9 & 20.4 & 27.6 & 0.0 & 0.0 & 62.0 \\
Biofilm-associated staphylococcal mastitis & 100.0 & 38.3 & 21.1 & 88.5 & 66.8 & 3.4 & 10.9 & 16.9 & 23.9 \\
Staphylococcal IMI & 74.1 & 40.2 & 5.6 & 40.7 & -64.8 & 29.2 & -27.9 & 39.0 & 74.4 \\
Biofilm-associated staphylococcal IMI & 76.5 & 42.6 & 33.3 & 87.9 & 40.0 & 8.3 & -19.2 & -70.0 & 24.1 \\
\hline
\end{tabular}

${ }^{1}$ First sampling point within the first $15 \mathrm{~d}$ after lambing; subsequent ones at monthly intervals thereafter. 